\title{
Effects of Prostaglandin Cyclic Endoperoxides on the Lung Circulation of Unanesthetized Sheep
}

\author{
Ronald E. Bowers, Earl F. Ellis, Kenneth L. Brigham, and John A. OAtes, \\ Pulmonary Circulation Center and Division of Clinical Pharmacology, \\ Department of Medicine, Vanderbilt University School of Medicine, Nashville, \\ Tennessee 37232
}

\begin{abstract}
A B S T RAC T Although prostaglandins $\mathrm{E}_{2}$ and $\mathrm{F}_{2 \alpha}$ have been suggested as mediators of the pulmonary hypertension seen after endotoxin infusion or during alveolar hypoxia, their precursors, the endoperoxides (prostaglandins $\mathrm{G}_{2}$ and $\mathrm{H}_{2}$ ) are much more potent vasoconstrictors in vitro. In this study we compared the effects of prostaglandin (PG) $\mathrm{H}_{2}$, a stable 9-methylene ether analogue of $\mathrm{PGH}_{2}\left(\mathrm{PGH}_{2}-\mathrm{A}\right), \mathrm{PGE}_{2}$, and $\mathrm{PGF}_{2 \alpha}$ on pulmonary hemodynamics in awake sheep. The animals were prepared to allow for measurement of (a) lung lymph flow; (b) plasma and lymph protein concentration; $(c)$ systemic and pulmonary vascular pressures; and $(d)$ cardiac output. We also determined the effect of prolonged $\mathrm{PGH}_{2}$-A infusions on lung fluid balance and vascular permeability by indicator dilution methods, and by assessing the response of lung lymph. Both $\mathrm{PGH}_{2}$ and $\mathrm{PGH}_{2}$-A caused a dose-related increase in pulmonary artery pressure: $0.25 \mu \mathrm{g} / \mathrm{kg} \times \min$ tripled pulmonary vascular resistance without substantially affecting systemic pressures. Both were 100 times more potent than $\mathrm{PGE}_{2}$ or $\mathrm{PGF}_{2 \alpha}$ in this preparation. $\mathrm{PGH}_{2}-\mathrm{A}$, as our analysis of lung lymph and indicator dilution measurements show, does not increase the permeability of exchanging vessels in the lung to fluid and protein. It does, however, augment lung fluid transport by increasing hydrostatic pressure in the pulmonary circulation. We conclude: $(a)$ that $\mathrm{PGH}_{2}$ is likely to be an important mediator of pulmonary vasoconstriction; $(b)$ its effects are probably not a result of its metabolites $\mathrm{PGE}_{2}$ or $\mathrm{PGF}_{2 \alpha}$.
\end{abstract}

\footnotetext{
This work was done while Dr. Bowers was supported by a National Research Service Award in interdisciplinary lung research from the National Heart and Lung Institute (HL 07123). This work was done during Dr. Brigham's tenure as an Established Investigator of the American Heart Association. Dr. Oates is the Joe and Morris Werthan Professor of Investigative Medicine.

Received for publication 20 February 1978 and in revised form 18 September 1978.
}

\section{INTRODUCTION}

The agents mediating the pulmonary hypertension seen with alveolar hypoxia and gram-negative endotoxin infusion have not been identified. Because prostaglandins $(P G)^{1} E_{2}$ and $F_{2 \alpha}$ are released from the lungs during these reactions, they have been implicated as the mediators, but neither is an impressive vasoconstrictor in vitro $(1,2)$. In contrast, their precursors, the endoperoxides $\mathrm{PGG}_{2}$ and $\mathrm{PGH}_{2}$, are powerful vasoconstrictors, $\cong 100$ times more potent in constricting isolated smooth muscle (3).

Because the endoperoxides are unstable and difficult to synthesize in the large amounts needed for in vivo studies, we first used a stable 9-methylene ether analogue of $\mathrm{PGH}_{2}\left(\mathrm{PGH}_{2}-\mathrm{A}\right.$; [15S] hydroxy-11 $\alpha, 9 \alpha-$ [epoxymethano] prosta-5Z, 13E-dienoic acid, [4]) to assess the effects of endoperoxides on pulmonary vascular pressures, permeability of the lung microcirculation, and lung fluid balance in awake sheep. We then prepared $\mathrm{PGH}_{2}$, itself, in amounts large enough for brief steady-state infusions, and compared its effects to those of the analogue, $\mathrm{PGE}_{2}$ and $\mathrm{PGF}_{2 \alpha}$.

$\mathrm{PGH}_{2}$ and $\mathrm{PGH}_{2}$-A were potent vasoconstrictors, 100 times more potent than $\mathrm{PGE}_{2}$ and $\mathrm{PGF}_{2 \alpha}$. $\mathrm{PGH}_{2}$ $A$, as our studies of lung lymph and indicator dilution measurements showed, did not increase the permeability of exchanging vessels in the lung to fluid and protein, although it did augment fluid transport by increasing hydrostatic pressure in these vessels.

\section{METHODS}

Materials. We prepared $\mathrm{PGH}_{2}$ by incubating arachidonic acid with sheep seminal vesicle microsomes. After isolating $\mathrm{PGH}_{2}$ by silicic acid chromatography, we confirmed the structure by mass spectrometry $(5,6)$. We stored $\mathrm{PGH}_{2}$ in an

${ }^{1}$ Abbreviations used in this paper: PG, prostaglandin; $\mathrm{PGH}_{2}-\mathrm{A}$, stable 9-methylene ether analogue of $\mathrm{PGH}_{2}$. 
acetone solution at $-60^{\circ} \mathrm{C}$ and infused it with normal saline so that the amount of acetone delivered was $<0.1 \mathrm{ml}$ over $15 \mathrm{~min}$. This amount of acetone infused alone had no effect on vascular pressures or lymph flow.

$\mathrm{PGH}_{2}$ analogue, which was supplied by Upjohn Co., Kalamazoo, Mich. was synthesized as described by Bundy (4). We stored $\mathrm{PGH}_{2}-\mathrm{A}$ in absolute ethanol solutions at $4^{\circ} \mathrm{C}$, then diluted it with normal saline shortly before an experiment.

$\mathrm{PGE}_{2}$ and $\mathrm{PGF}_{2 \alpha}$ were also supplied by Upjohn Co. We dissolved them in normal saline and adjusted $\mathrm{pH}$ to between 6 and 7 with bicarbonate buffer before infusion.

Experimental preparation. We prepared sheep by a series of thoracotomies as described (7-9). Through a left thoracotomy, we put catheters in the pulmonary artery and left atrium and a Doppler ultrasonic flow cuff (Park Electronics Laboratory, Beaverton, Oreg.) around the main pulmonary artery. In some sheep, we put a Foley balloon catheter in the left atrium. Several days later, through a right thoracotomy, we cannulated the efferent lymph vessel emerging from the caudal mediastinal lymph node, resected the tail of the node, and passed catheters into the thoracic aorta and vena cava through neck vessels. Because lymph flow from sheep prepared this way responds to changes in pulmonary venous pressure, but not to changes in systemic venous pressure, it comes primarily from the lungs (7).

After the last operation, we waited until the lung lymph flow, vascular pressures, and cardiac output were stable and the lymph was free of blood before doing experiments. In several sheep, lymph flow stopped spontaneously. We used these animals in experiments measuring only vascular pressures and cardiac output or for indicator dilution studies.

Protein analysis. We measured total protein concentration in lymph and blood plasma with an automated system (AutoAnalyzer, Technicon Instruments, Corp., Tarrytown, N. Y.) using a modified biuret method (10); duplicate samples differed $<5 \%$.

Assessment of vascular permeability. We used total protein concentrations to calculate protein osmotic pressure (II) from the regression equation of Landis and Pappenheimer (11). Then we calculated the difference between plasma and lymph protein osmotic pressure $(\Delta \Pi): \Delta \Pi=\Pi$ plasma $-\Pi$ lymph. After normalizing lymph flow and $\Delta \Pi$ to base line to compensate for variations among sheep, we compared graphically the relationship between $\Delta \Pi$ and lymph flow for these experiments to two relationships established by previous studies: $(a)$ increased pulmonary venous pressure and $(b)$ histamine infusion (3). The first relationship is an example of increased lymph flow caused by high pressure in pulmonary exchanging vessels of normal permeability, whereas the second is an example of high lung lymph flow due to high vascular permeability.

Indicator dilution studies. To obtain in vivo measurements of extravascular lung water, cardiac output, and pulmonary capillary permeability, we injected a bolus of ${ }^{51} \mathrm{Cr}-$ tagged erythrocytes, ${ }^{125} \mathrm{I}$-labeled albumin, $\left[{ }^{14} \mathrm{C}\right]$ urea, and $\left[{ }^{3} \mathrm{H}\right]$ water into the right atrium and sampled blood from the aorta as discussed in several earlier publications (12-16).

First we ran curves under base-line conditions, then infused $\mathrm{PGH}_{2}-\mathrm{A}$ at $0.01,0.10$, or $0.25 \mu \mathrm{g} / \mathrm{kg} \times \mathrm{min}$ into the superior vena cava and repeated curves during the steady-state response period. Later, we counted samples of blood for gamma and beta activity, plotted normalized time-concentration curves, calculated flow as the inverse of the area under the intravascular tracer curves, and calculated extravascular water volume and $\left[{ }^{14} \mathrm{C}\right]$ urea permeability surface area product using a Krogh-convolution circulatory model, the details of which have been published (16).

\section{Experimental protocols}

During all experiments the sheep were awake and standing in a cage. In each experiment we measured vascular pressures using calibrated miniature strain gauges (Micron Instruments, Inc., Los Angeles, Calif.) positioned at the level of the left atrium. With the pulmonary artery diameter (measured when we installed the flow cuff), and a signal proportional to the blood velocity from a Doppler flow meter (Parks Electronics model 802), we calibrated an electronic recorder (HewlettPackard 770 series Hewlett-Packard Co., Palo Alto, Calif.) and directly recorded blood flow in the pulmonary artery (17). We also recorded pulmonary and systemic vascular pressures continuously during each experiment. We measured lymph flow at 15-min intervals by recording the volume drained into graduated tubes, and we measured total protein concentration in plasma from blood drawn each hour and lymph pooled at 30 -min intervals.

\section{INCREASED PRESSURE STUDIES}

Once in each of nine sheep we measured responses to increases in left atrial pressure. After at least $1 \mathrm{~h}$ of base-line observation we inflated the left atrial balloon enough to increase left atrial pressure by $15-20 \mathrm{~cm} \mathrm{H}_{2} \mathrm{O}$ and kept pressure stable for $4 \mathrm{~h}$. A steady-state lymph flow rate was reached $\cong 2 \mathrm{~h}$ after the balloon was inflated (18).

\section{Prostaglandin STUdies}

Effects on pulmonary hemodynamics. (a) $\mathrm{PGH}_{2}-\mathrm{A}$ : We infused $\mathrm{PGH}_{2}$-A at $0.01 \mu \mathrm{g} / \mathrm{kg} \times \min$ (10 experiments in 8 sheep), $0.1 \mu \mathrm{g} / \mathrm{kg} \times \min$ (13 experiments in 8 sheep), or 0.25 $\mu \mathrm{g} / \mathrm{kg} \times \min (14$ experiments in 10 sheep) through the superior vena cava catheter. We measured base-line and steady-state cardiac output and vascular pressures. (b) $\mathrm{PGH}_{2}$ : Three times in three sheep we infused $\mathrm{PGH}_{2}$ at 0.1 or 0.25 $\mu \mathrm{g} / \mathrm{kg} \times \min$ into the superior vena cava catheter and measured base-line and steady-state cardiac output and vascular pressures. In one sheep we infused $0.1 \mu \mathrm{g} / \mathrm{kg} \times \min$ into the left atrium. (c) Three times in three sheep we infused $\mathrm{PGE}_{2}$ and $\mathrm{PGF}_{2 \alpha}$ at rates from 0.1 to $30 \mu \mathrm{g} / \mathrm{kg} \times$ min and measured steady-state base line and experimental cardiac output and vascular pressure.

Effects on lung lymph flow and protein concentration. (a) We infused $\mathrm{PGH}_{2}$-A at either $0.01 \mu \mathrm{g} / \mathrm{kg} \times \min (4$ times in 4 sheep), $0.10 \mu \mathrm{g} / \mathrm{kg} \times \min (8$ times in 8 sheep), or $0.25 \mu \mathrm{g} / \mathrm{kg}$ $\times$ min (10 times in 10 sheep) while measuring lung lymph flow, vascular pressures, and blood and lymph protein concentrations.

Indicator dilution studies. Nine times in seven sheep we infused $0.01,0.10$, and $0.25 \mu \mathrm{g} / \mathrm{kg} \times \min$ of $\mathrm{PGH}_{2}-\mathrm{A}$ into the superior vena cava, measuring steady-state base line and experimental cardiac output, extravascular lung water volume and $\left[{ }^{14} \mathrm{C}\right]$ urea permeability surface area product by quadruple indicator dilution methods before injection of $\mathrm{PGH}_{2}-\mathrm{A}$ and during the plateau of the pulmonary artery pressure response.

\section{PGH $_{2}$-A, INDOMETHACIN STUDIES}

Twice in two sheep we infused $\mathrm{PGH}_{2}-\mathrm{A}$ at 0.1 and $0.25 \mu \mathrm{g} /$ $\mathrm{kg} \times$ min, while giving $5 \mathrm{mg} / \mathrm{kg} \times \mathrm{h}$ of indomethacin intravenously beginning $1 \mathrm{~h}$ before $\mathrm{PGH}_{2}-\mathrm{A}$ infusion.

\section{Statistics}

Where the summary data are given, we show the average $\pm \mathrm{SE}$ of measurement. We compared the significance of data 
TABLE I

Effects of Prostaglandin Endoperoxide $\left(\mathrm{PGH}_{2}\right)$ on Steady-State Pulmonary Hemodynamics

\begin{tabular}{|c|c|c|c|c|c|}
\hline \multirow[b]{3}{*}{ Infusion rate } & \multicolumn{5}{|c|}{ Continuous infusion into the superior vena cava } \\
\hline & \multicolumn{2}{|c|}{ Mean pressure } & \multirow[b]{2}{*}{ Cardiac output } & \multirow[b]{2}{*}{$\begin{array}{l}\text { Pulmonary vascular } \\
\text { resistance }\end{array}$} & \multirow[b]{2}{*}{$\begin{array}{l}\text { Pulmonary vascular } \\
\text { resistance }\end{array}$} \\
\hline & $\begin{array}{l}\text { Pulmonary } \\
\text { artery }\end{array}$ & $\begin{array}{c}\text { Left } \\
\text { atrium }\end{array}$ & & & \\
\hline & \multicolumn{2}{|c|}{$\mathrm{cm} \mathrm{H}_{2} \mathrm{O}$} & $\mathrm{ml} / \mathrm{s}$ & $\left(\mathrm{cm} \mathrm{H}_{2} \mathrm{O} \cdot \mathrm{s}\right) / \mathrm{ml}$ & experimental/base line \\
\hline Base line $(n=3)$ & $21 \pm 4^{*}$ & $1 \pm 3$ & $88 \pm 8$ & $0.25 \pm 0.07$ & 1.00 \\
\hline $0.10 \mu \mathrm{g} / \mathrm{kg} \times \min (n=3)$ & $42 \pm 6$ & $5 \pm 1$ & $96 \pm 9$ & $0.50 \pm 0.10$ & $2.00 \pm 1$ \\
\hline $0.25 \mu \mathrm{g} / \mathrm{kg} \times \min (n=1)$ & 53 & 5 & 80 & 0.73 & 2.90 \\
\hline
\end{tabular}

$*$ Mean \pm SEM.

by the Wilcoxon rank sum test or Student's $t$ test, accepting $P<0.05$ as significant. Where appropriate, we tested data for normal distribution using the Kolmogorov-Smirnov test at $80 \%$ confidence level (19).

\section{RESULTS}

Increased left atrial pressure. We evaluated the effects of elevated pulmonary venous pressure once in each of nine sheep. Lymph flow and lymph to plasma protein concentration ratios were like the results reported $(18,6,7)$ : for an average increase in left atrial pressure of $14 \mathrm{~cm} \mathrm{H}_{2} \mathrm{O}$, lymph flow doubled, and lymph protein concentration always fell absolutely and relative to plasma.

Infusion of $\mathrm{PGH}_{2}$ and its analogue: hemodynamics. $\mathrm{PGH}_{2}$ and its analogue $\mathrm{PGH}_{2}-\mathrm{A}$ had identical hemodynamic effects. The data are summarized in Tables $I$ and II and illustrated in Fig. 1. Both substances caused a dose-related increase in pulmonary vascular resistance leading to a threefold increase in pulmonary artery pressure at the $0.25 \mu \mathrm{g} / \mathrm{kg} \times \min$ dose. There was a small, dose-related drop in cardiac output. Infusion of $\mathrm{PGH}_{2}$ into the left atrium caused no change in pulmonary or systemic pressures or cardiac output, but left atrial $\mathrm{PGH}_{2}$-A infusions caused pulmonary hemodynamic changes similar to intravenous infusion of the same substance.

$\mathrm{PGE}_{2}$ and $\mathrm{PGF}_{2 \alpha}$ caused little change in pulmonary vascular resistance until the dose reached $10 \mu \mathrm{g} / \mathrm{kg}$ $\times$ min, almost 100 times the effective $\mathrm{PGH}_{2}$ dose (Fig. 2). At higher doses, pulmonary arterial and left atrial pressure rose as cardiac output fell. At the higher doses the animals developed respiratory distress and often collapsed.

TABLE II

Effects of the Endoperoxide Analogue $\left(\mathrm{PGH}_{2} \mathrm{~A}\right)$ on Steady-State Pulmonary Hemodynamics

\begin{tabular}{|c|c|c|c|c|c|c|}
\hline \multirow[b]{3}{*}{ Infusion rate } & \multicolumn{6}{|c|}{ Continuous infusions into the superior vena cava } \\
\hline & \multicolumn{2}{|c|}{ Mean pressure } & \multirow{2}{*}{$\begin{array}{c}\frac{\text { Systolic }}{\text { diastolic }} \\
\text { pressure } \\
\text { aorta }\end{array}$} & \multirow[b]{2}{*}{ Cardiac output } & \multirow[b]{2}{*}{$\begin{array}{l}\text { Pulmonary vascular } \\
\text { resistance }\end{array}$} & \multirow[b]{2}{*}{$\begin{array}{l}\text { Pulmonary vascular } \\
\text { resistance }\end{array}$} \\
\hline & $\begin{array}{l}\text { Pulmonary } \\
\text { artery }\end{array}$ & $\begin{array}{c}\text { Left } \\
\text { atrium }\end{array}$ & & & & \\
\hline & \multicolumn{2}{|c|}{$\mathrm{cm} \mathrm{H}_{2} \mathrm{O}$} & Torr & $\mathrm{ml} / \mathrm{s}$ & $\left(\mathrm{cm} \mathrm{H} \mathrm{H}_{2} \mathrm{O} \cdot \mathrm{s}\right) / \mathrm{ml}$ & experimental/base line \\
\hline Base line $(n=17)$ & $21 \pm 1$ & $1 \pm 1$ & $\frac{107 \pm 2}{74 \pm 2}$ & $99 \pm 5$ & $0.22 \pm 0.02$ & 1.0 \\
\hline $0.01 \mu \mathrm{g} / \mathrm{kg} \times \min (n=10)$ & $25 \pm 1^{*}$ & $2 \pm 1$ & $\frac{109 \pm 3}{75 \pm 3}$ & $96 \pm 7^{*}$ & $0.28 \pm 0.02 *$ & $1.2 \pm 105^{*}$ \\
\hline $0.1 \mu \mathrm{g} / \mathrm{kg} \times \min (n=13)$ & $37 \pm 4^{*}$ & $2 \pm 1$ & $\frac{108 \pm 2}{70 \pm 6}$ & $90 \pm 6^{*}$ & $0.42 \pm 0.04^{*}$ & $2.0 \pm 0.20^{*}$ \\
\hline $0.25 \mu \mathrm{g} / \mathrm{kg} \times \min (n=14)$ & $52 \pm 2^{*}$ & $1 \pm 1$ & $\frac{112 \pm 2}{80 \pm 4}$ & $86 \pm 5^{*}$ & $0.62 \pm 0.05^{*}$ & $2.9 \pm 0.14^{*}$ \\
\hline
\end{tabular}

Average weight of the sheep, $41.5 \mathrm{~kg}$ (mean \pm SEM).

* Significantly different from base line $(\mathrm{P}<0.05)$. 

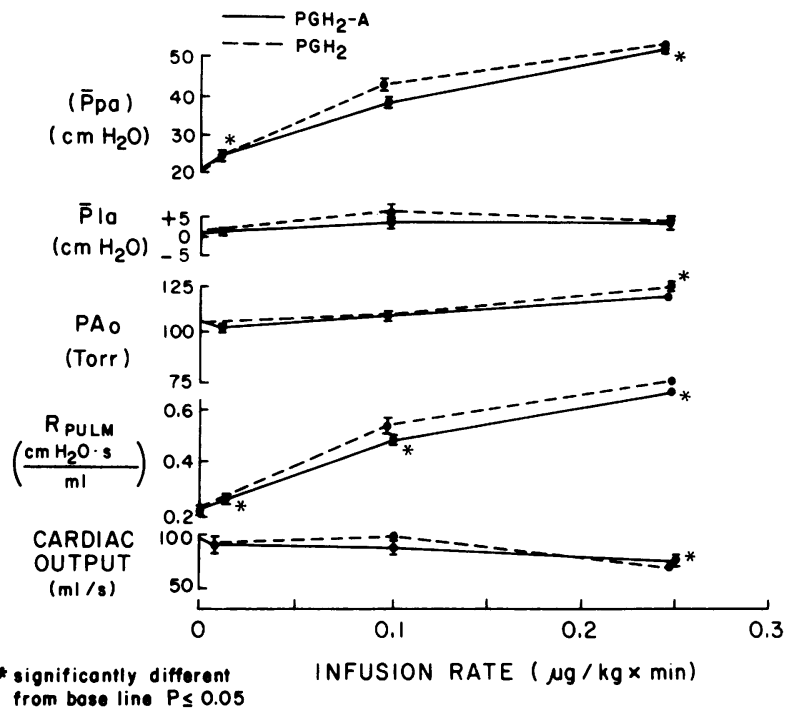

Figure 1 Hemodynamic effects of $\mathrm{PGH}_{2}-\mathrm{A}$ and $\mathrm{PGH}_{2}$ in the pulmonary circulation. Pिa, mean pulmonary artery pressure; Pla, mean left atrial pressure; PAo, systolic pressure in the aorta; $\mathbf{R}$ pulm, pulmonary vascular resistance.

$\mathrm{PGH}_{2}-\mathrm{A}$ : effects on lung lymph flow and protein concentrations. As shown in Fig. 3, infusion of $\mathrm{PGH}_{2}-$ A caused a dose-related increase in lung lymph flow, corresponding to increases in pulmonary artery pressure. Although the lymph flow increased substantially at higher doses, the lymph protein concentration fell. These data are summarized in Table III. The fall in lymph protein concentration as lymph flow increases is a characteristic effect of high pressure (8). In fact, the effect of $\mathrm{PGH}_{2}-\mathrm{A}$ and high left atrial pressure on $\Delta \Pi$ are indistinguishable (Fig. 4). The $\Delta \Pi$ increases linearly with lymph flow after both interventions as a result of the fall in lymph protein concentration relative to

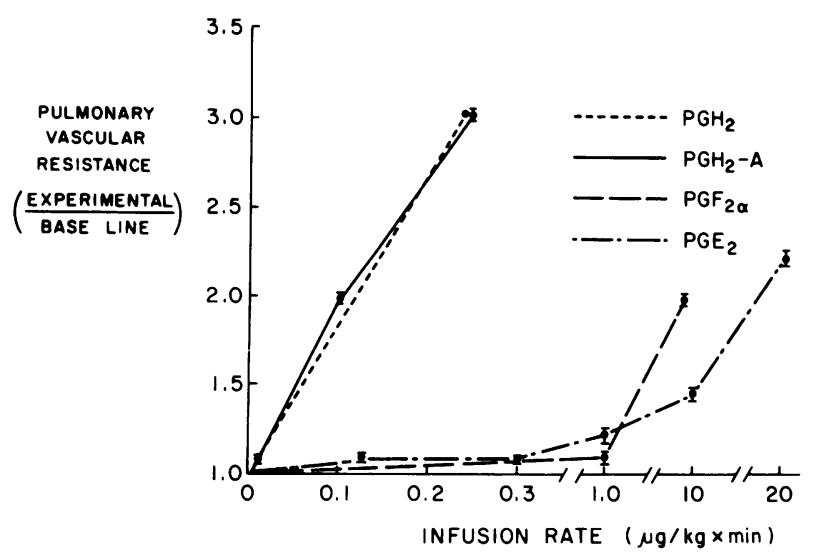

FIGURE 2 Comparison of the effects of $\mathrm{PGH}_{2}, \mathrm{PGH}_{2}-\mathrm{A}, \mathrm{PGE}_{2}$, and $\mathrm{PGF}_{2 \alpha}$ on pulmonary vascular resistance normalized to base line.

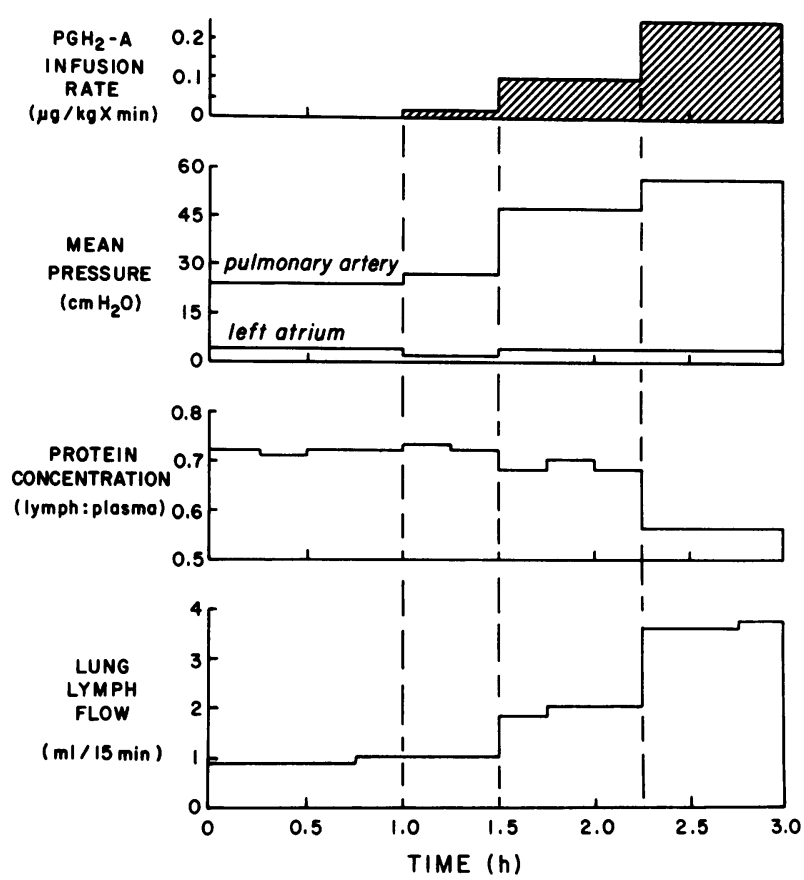

FIGURE 3 Typical response of pulmonary vascular pressures, lymph flow and lymph:plasma protein concentration ratio to increasing intravenous infusion rates of $\mathrm{PGH}_{2}-\mathrm{A}$. Data are averaged over 15-min intervals.

plasma protein concentration (Table III). The two regression lines (of $\Delta \Pi$ vs. lymph flow) in Fig. 4, one derived from high left atrial pressure experiments, the other from endoperoxide studies, are not significantly different $(P>0.3)$, and are in clear contrast to the line derived from histamine studies where permeability was increased.

$\mathrm{PGH}_{2}-\mathrm{A}$ infusions after treatment with indomethacin. Pretreatment with $5 \mathrm{mg} / \mathrm{kg} \times \mathrm{h}$ of indomethacin had no effect on the response of pulmonary pressures or lymph flow rate to $\mathrm{PGH}_{2}-\mathrm{A}$ infusion.

Indicator dilution studies. There was no significant change from base line in the steady-state extravascular lung water or $\left[{ }^{14} \mathrm{C}\right]$ urea permeability surface area product during $\mathrm{PGH}_{2}-\mathrm{A}$ infusions. The data are summarized in Table IV.

\section{DISCUSSION}

This study shows that $\mathrm{PGH}_{2}$ and a 9-methylene cyclic ether analogue are potent and specific pulmonary vasoconstrictors in doses which have little effect on the systemic circulation. A $0.25-\mu \mathrm{g} / \mathrm{kg} \times \min$ i.v. dose tripled pulmonary vascular resistance, whereas as little as $0.01 \mu \mathrm{g} / \mathrm{kg} \times \mathrm{min}$ had an effect. Although studies in vitro $(3,20)$ suggest this potency of the endoperoxide, its specificity for the pulmonary circulation in vivo is unexpected. Few, if any, known endogenous sub- 
TABLE III

Effects of the Endoperoxide Analogue on Steady-State Lung Lymph Flow

and Protein Concentration

\begin{tabular}{|c|c|c|c|c|}
\hline \multirow[b]{3}{*}{ Infusion rate } & \multicolumn{4}{|c|}{ Continuous infusions into the superior vena cava } \\
\hline & \multirow[b]{2}{*}{ Lymph flow } & \multicolumn{2}{|c|}{ Total protein concentration } & \multirow[b]{2}{*}{ Protein concentration } \\
\hline & & Plasma & Lymph & \\
\hline & experimental/base line & \multicolumn{2}{|c|}{ g/dl } & lymph/plasma \\
\hline Base line $(n=10)$ & 1.00 & $6.4 \pm 0.2$ & $4.3 \pm 0.2$ & $0.67 \pm 0.01$ \\
\hline $0.01 \mu \mathrm{g} / \mathrm{kg} \times \min (n=4)$ & $1.13 \pm 0.1 * t$ & $6.4 \pm 0.5$ & $4.1 \pm 5^{*}$ & $0.64 \pm 0.03$ \\
\hline $0.10 \mu \mathrm{g} / \mathrm{kg} \times \min (n=8)$ & $1.65 \pm 0.1^{*}$ & $6.7 \pm 0.3$ & $4.0 \pm 0.2^{*}$ & $0.59 \pm 0.02^{*}$ \\
\hline $0.25 \mu \mathrm{g} / \mathrm{kg} \times \min (n=10)$ & $2.50 \pm 0.3^{*}$ & $6.6 \pm 0.2$ & $3.4 \pm 0.2^{*}$ & $0.51 \pm 0.03^{*}$ \\
\hline
\end{tabular}

* Significantly different from base line $(P<0.05)$.

$\downarrow$ Mean \pm SEM.

stances are such powerful, yet specific pulmonary vasoconstrictors.

Could an endoperoxide be the pressor agent mediating endotoxin-induced pulmonary hypertension? In calfs, Anderson et al. (21) blocked this effect of endotoxin with indomethacin and implicated prostaglandins as mediators. Anderson thought $\mathbf{P G F}_{2 \alpha}$ was probably the agent, because the concentration of this prostaglandin rose in pulmonary venous blood after endotoxin infusion. Our study shows that the precursor endoperoxide $\mathrm{PGH}_{2}$ is a 100 times more potent pulmonary vasoconstrictor than $\mathbf{P G F}_{2 \alpha}$. Since Anderson et al. (21) found that the lung releases considerable amounts of $\mathrm{PGF}_{2 \alpha}$ in response to endotoxin infusion, $\mathrm{PGH}_{2}$ (an obligatory intermediate) must have been formed in substantial amounts too. If so, $\mathbf{P G H}_{\mathbf{2}}$ is more likely to have caused pulmonary hypertension than $\mathrm{PGF}_{2 \alpha}$.

Do $\mathrm{PGH}_{2}$ and $\mathrm{PGH}_{2}-\mathrm{A}$ act by aggregating platelets?

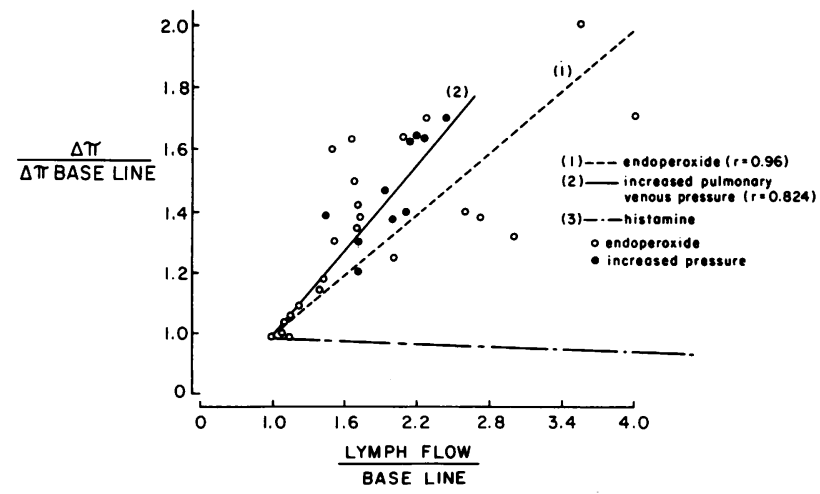

FIGURE 4 Normalized net osmotic pressure difference $(\Delta \Pi$ $=\Pi$ plasma- $\Pi$ lymph) as a function of normalized lymph flow. The null hypothesis that lines (1) and (2) are derived from the same population cannot be rejected $(P>0.30)$. Line (3) derived from studies of histamine infusion shows the characteristic failure of $\Delta \Pi$ to increase with lymph flow when vascular permeability is high.
Both will aggregate platelets in vitro $(3,5)$, but their effects on pulmonary vascular resistance probably are not a result of intravascular platelet aggregation because: $(a)$ the high pulmonary artery pressure produced by infusion of $\mathrm{PGH}_{2}$ and $\mathrm{PGH}_{2}-\mathrm{A}$ returned to normal within 5 min after the infusion was stopped; and $(b)$ infusion of $\mathrm{PGH}_{2}$ into the left atrium had no apparent physiological effects. If platelet aggregation and vascular plugging were involved the effect should persist for longer than $5 \mathrm{~min}$.

From our data, we cannot determine whether the effects of $\mathrm{PGH}_{2}$ are a direct result of its action on the smooth muscle of the resistance vessels of the lung, or whether conversion to its metabolite thromboxane $A_{2}$ is necessary first. Thromboxane $A_{2}$ is more potent than $\mathrm{PGH}_{2}$ in contracting large arterial smooth muscle and in inducing aggregation of platelets in vitro $(22,23)$. Because it is formed from $\mathrm{PGH}_{2}$ in the lung (24), it is possible that the hemodynamic effects of $\mathrm{PGH}_{2}$ are mediated through this more active metabolite. Our finding that $\mathrm{PGH}_{2}-\mathrm{A}$, the analogue (which is not metabolized to thromboxane $A_{2}$ ), had effects similar to those of biosynthesized $\mathrm{PGH}_{2}$ suggests that $\mathrm{PGH}_{2}$ itself may cause vasoconstriction. However, if the analogue mimics thromboxane $A_{2}$ physiologically, our conclusion that the identical vasoconstriction $\mathrm{PGH}_{2}$ and $\mathrm{PGH}_{2}-\mathrm{A}$ cause is an innate effect of both may be wrong. Instead, $\mathrm{PGH}_{2}$ 's conversion to, and $\mathrm{PGH}_{2}-\mathrm{A}^{\prime}$ 's imitation of, thromboxane $A_{2}$ could explain their common effect.

The response to infusion of exogenous $\mathrm{PGH}_{2}$ into the pulmonary circulation does not prove that $\mathrm{PGH}_{2}$, when synthesized in the lung, has an identical effect. This could occur if $\mathrm{PGH}_{2}$ is synthesized in amounts comparable to those infused and if $\mathrm{PGH}_{2}$ has access to the smooth muscle of the resistance vessels. The exquisite sensitivity of the pulmonary circulation to $\mathrm{PGH}_{2}$ suggests that amounts synthesized in the lung could be physiologically significant. Lung vessels would also 
TABLE IV

The Effect of Endoperoxide Analogue Infusion on Indicator Dilution Lung Water and $\left[{ }^{14} \mathrm{C}\right]$ Urea Permeability Surface Area Products*

\begin{tabular}{|c|c|c|c|c|}
\hline & \multirow[b]{2}{*}{ Base line } & \multicolumn{3}{|c|}{ Infusion rate, $\mathrm{PGH}_{2}-\mathrm{A}$} \\
\hline & & 0.01 & 0.10 & 0.25 \\
\hline & & \multicolumn{3}{|c|}{$\mu g / k g \times \min$} \\
\hline Extravascular lung water, $m l$ & $229 \pm 35 \ddagger$ & $243 \pm 40$ & $255 \pm 32$ & $230 \pm 36$ \\
\hline Number of studies & 9 & 5 & 9 & 9 \\
\hline \multicolumn{5}{|l|}{$\left[{ }^{14} \mathrm{C}\right]$ Urea permeability } \\
\hline Surface area product, $\mathrm{ml} / \mathrm{s}$ & $10 \pm 1$ & $11.5 \pm 1.6$ & $10 \pm 1$ & $11.9 \pm 1.3$ \\
\hline Number of studies & 8 & 7 & 8 & 7 \\
\hline
\end{tabular}

* Average sheep body weight, $41.1 \pm 2 \mathrm{~kg}$.

$\ddagger$ Mean \pm SEM.

constrict in response to $\mathrm{PGH}_{2}$ released into venous blood by another organ. This effect might be particularly important if the ability of the lung to metabolize $\mathrm{PGH}_{2}$ were impaired by disease.

The results of this study agree with those of Kadowitz et al. (25) who found $\mathrm{PGH}_{2}$-A to be a potent pulmonary vasoconstrictor in dogs. But, our findings on the effects of $\mathrm{PGH}_{2}$ itself differ from those of Kadowitz et al. $\mathrm{He}$ found $\mathrm{PGH}_{2}$ to be weaker than $\mathrm{PGH}_{2}-\mathrm{A}$, while we find it to be equivalent in strength. This difference may have occurred because we gave $\mathrm{PGH}_{2}$ by continuous infusion and Kadowitz et al. used a $2-\mu \mathrm{g}$ bolus. It is interesting that Kadowitz et al. found that $\mathrm{PGH}_{2}$ contracted isolated pulmonary veins more powerfully than $\mathbf{P G H}_{\mathbf{2}}$-A.

Vascular permeability. The equivalent effects of high pulmonary venous pressures and $\mathrm{PGH}_{2}-\mathrm{A}$ infusion on lung lymph protein concentration and osmotic pressures (Fig. 4) indicate that $\mathrm{PGH}_{2}-\mathrm{A}$ causes pulmonary hypertension without increasing vascular permeability. Others have found that prostaglandins alter permeability in some vascular beds $(26,27)$ but we found no evidence that lung vessel integrity changed. This effect is like that of serotonin but unlike the response to histamine in this preparation: histamine causes increased flow of lymph with a relatively high protein concentration (8), whereas serotonin causes an increased flow of lymph of low protein content (9). With histamine, the osmotic pressure difference at high lymph flow falls, but with serotonin, mechanically increased pulmonary venous pressure, and, as this study shows, $\mathbf{P G H}_{2}-\mathrm{A}$ infusion, the oncotic pressure difference between lymph and plasma increases as lymph flow increases (Fig. 4). Thus, the increase in transvascular fluid filtration caused by the prostaglandins is apparently due solely to their effects on pressure in exchanging vessels.

Inactivation of $\mathrm{PGH}_{2}$ in vivo. $\mathrm{PGH}_{2}$ was apparently rapidly inactivated in the sheep circulation because injections into the left atrium did not change systemic or pulmonary pressures. This indicates that $\mathbf{P G H}_{2}$ was inactivated during one passage from the left atrium to the pulmonary circulation.

Site of action of $\mathrm{PGH}_{2}-\mathrm{A}$. Although we cannot state with certainty the site of action of $\mathrm{PGH}_{2}-\mathrm{A}$, at least some of the vasoconstriction must have been downstream from exchanging vessels. If the vasoconstriction had all been upstream to the exchanging site, lymph flow should not have increased. The latter phenomenon, pulmonary hypertension without increased lymph flow, is characteristic of the response of alveolar hypoxia in this preparation, as Bland et al. (28) showed. This difference between the effects of $\mathrm{PGH}_{2}$ $A$ infusions. and alveolar hypoxia suggests that prostaglandin endoperoxides do not mediate hypoxic pulmonary vasoconstriction.

\section{CONCLUSIONS}

(a) $\mathrm{PGH}_{2}$ and $\mathrm{PGH}_{2}-\mathrm{A}$ are potent vasoconstrictors in the pulmonary circulation in doses that have little effect on the systemic circulation. (b) $\mathrm{PGH}_{2}-\mathrm{A}$ does not increase lung microvascular permeability, but increases filtration from lung exchanging vessels by increasing vascular pressures. $(c)$ Because it is much more potent, $\mathrm{PGH}_{2}$ (or an active metabolite) is more likely to be an important mediator of pulmonary vasoconstriction than either $\mathrm{PGE}_{2}$ or $\mathrm{PGF}_{2 \alpha}$. (d) $\mathbf{P G H}_{2}$ is rapidly inactivated in the sheep circulation. (e) $\mathrm{PGH}_{2}$-A causes some vasoconstriction downstream to exchanging vessels in the lung.

\section{ACKNOWLEDGMENTS}

We acknowledge the valuable technical assistance of Patty J. Owen, Lou H. Scott, and Ann Payne in these studies, and thank Dewain Patterson for typing the manuscript.

This work was supported by grants HL 19153 (Specialized Center of Research in Pulmonary Vascular Diseases) and GM 15431. 


\section{REFERENCES}

1. Alpert, J. S., F. W. Haynes, P. A. Knutson, J. E. Dolen, and L. Dexter. 1973. Prostaglandins and the pulmonary circulation. Prostaglandins. 3: 756-765.

2. Kadowitz, P. J., P. D. Joiner, and A. L. Hyman. 1974. Effects of prostaglandins $E_{1}$ and $F_{2 \alpha}$ on the swine pulmonary circulation. Proc. Soc. Exp. Biol. Med. 145: 1258-1261.

3. Hamberg, J., P. Hedgvist, K. Strandberg, J. Svensson, and B. Samuelsson. 1975. Prostaglandin endoperoxides IV: effects on smooth muscle. Life Sci. 16: 451-462.

4. Bundy, G. L. 1975. The synthesis of prostaglandin endoperoxide analogs. Tetrahedron Lett. 24: 1957-1960.

5. Hamberg, M., J. Svensson, T. Wakabayshi, and B. Samuelsson. 1974. Isolation and structure of two endoperoxides that cause platelet aggregation. Proc. Natl. Acad. Sci. U. S. A. 71: 345-349.

6. Ellis, E., O. Oelz, J. Roberts II, A. Payne, B. Sweetman, A. Nies, and J. Oates. 1976. Coronary arterial smooth muscle contraction by a substance released from platelets: evidence that it is Thromboxane $\mathrm{A}_{2}$. Science (Wash. D. C.). 193: 1135-1137.

7. Staub, N., R. Bland, K. Brigham, R. Demling, J. Erdmann, and W. Woolverton. 1975. Preparation of chronic lung lymph fistulas in sheep. J. Surg. Res. 19: 315-320.

8. Brigham, K., and P. Owen. 1975. Increased sheep lung vascular permeability caused by histamine. Circ. Res. 37: 647-657.

9. Brigham, K., and P. Owen. 1975. Mechanism of the serotonin effect on lung transvascular fluid and protein movement in awake sheep. Circ. Res. 36: 761-769.

10. Failing, J., M. Buckley, and D. Zak. 1960. Automatic determination of serum proteins. Am. J. Clin. Pathol. 33: 83-88.

11. Landis, E., and J. Pappenheimer. 1963. Exchange of substances through capillary walls. Handb. Physiol. 2 (Sect. 2 Am. Physiol. Soc.): 961-1034.

12. Brigham, K., and J. Snell. 1973. In vivo assessment of pulmonary vascular integrity in experimental pulmonary edema. J. Clin. Invest. 52: 2041-2052.

13. Brigham, K., L. Ramsey, J. Snell, and C. Merritt. 1971. On defining the pulmonary extravascular water volume. Circ. Res. 29: 385-397.

14. Crone, C. 1963. Permeability of capillaries in various organs as determined by use of the "indicator diffusion" method. Acta. Physiol. Scand. 58: 292-305.

15. Harris, T. R., D. R. Rowlett, and K. L. Brigham. 1976. The identification of pulmonary capillary permeability from multiple indicator data. Microvasc. Res. 12: 177-195.

16. Rowlett, D., and T. Harris. 1976. A comparative study of organ models and numerical techniques for the evaluation of capillary permeability from multiple indicator data. Math. Biosci. 29: 273-298.
17. Brody, W. R., and J. D. Meindl. 1974. Theoretical Analysis of the Continuous Wave Doppler Ultrasonic Flowmeter, IEEE (Inst. Electr. Electron. Eng.) Trans. Biomed. Eng. BME-21: 183-192.

18. Erdmann, J. A., T. R. Vaughan, K. L. Brigham, W. C. Woolverton, and N. C. Staub. 1975. Effect of increased vascular pressure on lung fluid balance in unanesthetized sheep. Circ. Res. 37: 271-284.

19. Snedecor, W., and W. Cochran. 1967. In Statistical Methods Applied to Experiments in Agriculture and Biology. Iowa State University Press, Ames, Iowa. 6th edition. 95-101 and 128.

20. Chijimatsu, Y., T. V. Nguyen, and S. I. Said. 1977. Effects of prostaglandin endoperoxide analogs on contractile elements in lung and gastrointestinal tract. Prostaglandins. 13: 909-946.

21. Anderson, F., T. Tsagaris, W. Jubiz, and H. Kuida. 1973. Prostaglandin $\mathrm{F}$ and $\mathrm{E}$ levels during endotoxin-induced pulmonary hypertension in calves. Am. J. Physiol. 228: 1470-1482.

22. Hamberg, M., J. Svensson, and B. Sammuelsson. 1975. Thromboxanes: a new group of biologically active compounds derived from prostaglandin endoperoxides. 1975. Proc. Natl. Acad. Sci. U. S. A. 72: 2994-2998.

23. Svensson, J., K. Strandberg, T. Tuveno, and M. Hamberg. 1977. thromboxane $A_{2}$ : effects on airway and vascular smooth muscle. Prostaglandins. 14: 425-436.

24. Hamberg, M., J. Svensson, J. Hedqvist, K. Strandberg, and B. Samuelsson. 1976. Involvement of endoperoxides and thromboxanes in anaphylactic reactions. In Advances in Prostaglandin and Thromboxane Research. B. Samuelsson and R. Paoletti, editors Raven Press, New York. 1: 495-501.

25. Kadowitz, P. J., C. A. Gruetter, D. B. McNamara, R. R. Gorwan, E. W. Spannhake, and A. L. Hyman. 1977. Comparative effects of endoperoxide $\mathrm{PGH}_{2}$ and an analog on the pulmonary vascular bed. J. Appl. Physiol. 42: 953958.

26. Kaley, G., E. J. Messina, and R. Weiner. 1972. The role of prostaglandins in microcirculatory regulation and inflammation. In Prostaglandins and Cellular Biology, ALZA Conference Series. P. Ramwell and B. Pharriss, editors. Plenum Publishing Corp., New York. 309322.

27. Glenn, E. M., B. J. Bowman, and N. A. Rohloff. 1972. Pro-inflammatory effects of certain prostaglandins. In Prostaglandins in Cellular Biology, ALZA Conference Series. P. Ramwell and B. Pharriss, editors. Plenum Publishing Corp., New York. 329-342.

28. Bland, R. D., R. H. Demling, S. L. Selinger, and N. C. Staub. 1977. Effects of alveolar hypoxia on lung fluid and protein transport in unanesthetized sheep. Circ. Res. 40: 269-274. 